\title{
小児重症頭部外傷ガイドライン
}

\author{
荒木尚師田信人
}

\section{Guidelines for the Management of Severe Traumatic Brain Injury in Children}

by

Takashi Araki, M.D. and Nobuhito Morota, M.D.

from

Division of Neurosurgery, Department of Surgery, National Medical Center for Children and Mothers,

National Center for Child Health and Development

The present pediatric traumatic brain injury guidelines outline several important topics of treatment and provide a detaileb, evidence-based system for management of children with severe TBI, although there are limitations due to the lack of strong evidence or proven efficacy for obtaining better functional outcome of the patient. Especially, securing the airway and maintaining proper breathing are paramount in the first step of the pediatric TBI management in order to prevent any extension of secondary brain injury. Breakthrough discoveries in the treatment of pediatric TBI can be expected, along with the development of therapeutic interventions by focusing on the patient's high cognitive function and diagnostic imaging studies in the future.

(Received July 21, 2011; accepted August 29, 2011)

Key words : traumatic brain injury, children, guidelines, management

\section{Jpn J Neurosurg（Tokyo） $20: 809-817,2011$}

\section{はじめに}

「頭部外傷」は小児の死亡率, 有病率の主要な原因であ り, 特に重症頭部外傷の死亡率は $20 \sim 30 \%$ ときわめて高 い29). 一方, 救命しえた場合でも, 神経学的後遺症や高 次脳機能障害などを合併した場合，本人や家族，社会が 生涯にわたり負担する医療費は莫大なものとなる。さ さら に近年, 虐待による頭部外傷の発生頻度が増加しており, 「軽微な外傷など」により発症する乳幼児急性硬膜下血腫 への対応も，従来とは異なる診断プロセスが必要とされ ている，同時に被虐待児は一般的に養育に多くの問題を 抱宇ており，深刻な社会問題でもある1016)25).

このように，頭部外傷は子どもの生涯を通じて影響を
もたらし, 特に急性期病態への対応が機能予後に最も強 くかかわる因子であることから，二次的脳損傷を最低限 にするための努力が必要である.

また小児頭部外傷に対応する際には，成長発達を考慮 する必要があることや，解剖・生理学的な特徵が特有の 病態をもたらすため, ガイドラインとして診断・治療を 標準化することは容易ではない（Fig. 1).

2000 年に日本脳神経外傷学会から『重症頭部外傷治 療・管理のガイドライン』が出版されている ${ }^{38)}$. 初版の 序では, “標準化された治療を行うことが治療の成績や転 帰の向上に繋がるもの”と期待され, “医学教育の向上や 新しい治療法の開発などの指針となること”や, “不要な 治療・管理が減少し医療コストが削減されること”を期

国立成育医療研究センター脳神経外科／テ $157-8535$ 世田谷区大蔵 2-10-1〔連絡先：荒木 尚〕

Address reprint requests to: Takashi Araki, M.D., Division of Neurosurgery, Department of Surgery, National Medical Center for Children and Mothers, National Center for Child Health and Development, 2-10-1 Okura, Setagaya-ku, Tokyo 157-8535, Japan 


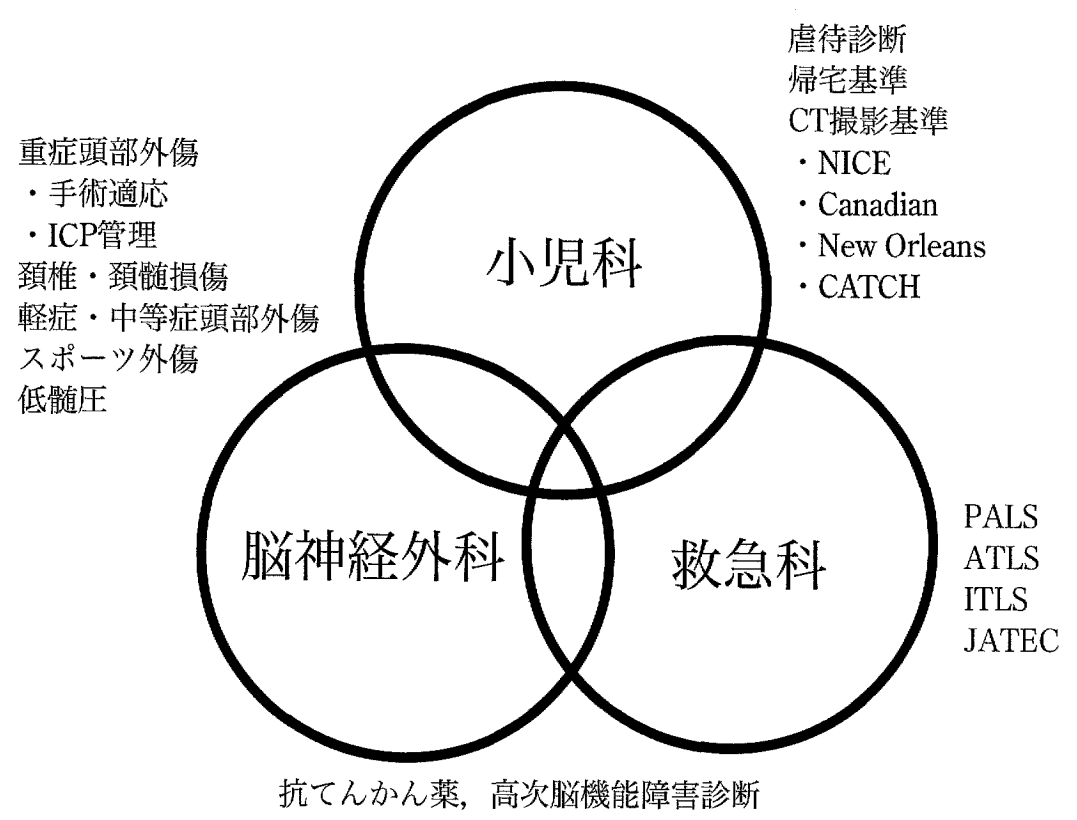

Fig. 1 Various guidelines for the management of head injury in children related to the interests of each department

ICP: intracranial pressure, NICE: National Institute for Health and Clinical Excellence, CATCH : Canadian Assessment of Tomography for Childhood Head injury, PALS: Pediatric Advanced Life Support, ATLS: Advanced Trauma Life Support, ITLS: International Trauma Life Support, JATEC : Japan Advanced Trauma Evaluation and Care

待して作成されたと明記されており，ガイドラインが， 現場において担当医が知るべき「minimum essential」と は何か，何をすべきでないか，を示すことを理念として 編纂された経緯が何える。

本稿では, 内外のガイドライン1)2238)が示す治療指針を 改めて解説し, 近年報告された臨床研究結果を踏まえ, 2012 年に予定される第 3 版の改訂のポイントについて 考察する.

\section{小児頭部外傷における二次性脳損傷}

二次性脳損傷とは,一次性脳損傷により生じた低血圧, 異常高血圧，低酸素，低血圧などの全身性因子が誘発す る一連の反応によって生じる脳への続発的損傷をい $j^{6)}$. 一次性脳損傷により誘発される生理学的・病態生 理学的反応には, (1)脳血流自動調節能の障害, (2)血液脳 関門の破緃，(3)炎症の連鎖反応，(4)酸素化ストレス，(5) 興㚛毒性，6アポトーシス等遅発性神経細胞死，などが 挙げられ，個々の変化により脳局所またはびまん性に神 経細胞内外に浮腫を生じることが知られる。脳浮腫の進 行はさらなる虚血性脳損傷を悪化させ, 悪循環を形成す ることになる4)17)39).

小児は容易に気道閉塞を起こし，低酸素や高炭酸ガス
血症を合併するため，呼吸循環動態が不安定になりやす い.また，徐脈にもなりやすく，心拍出量低下を伴う結 果，脳への血液・酸素供給が減少する，多発外傷では頭 蓋外損傷による失血が容易に全身循環動態を破綻させ る.ガイドラインでは，救急初期治療の段階から，全身 循環動態の安定化を優先したアプローチを推奨してい る.

小児重症頭部外傷におけるびまん性脳腫脹は，未熟な 自動調節能による充血現象と解积されていたが，むしろ 自動調節能が未熟であるがため脳血流が体血圧依存とな り，収縮期低血圧により容易に脳虚血をもたらすと考元 られている。.また，被虐待児の頭部外傷例における検討 では, 中枢神経特有の病理学的変化が指摘されており, 放射線学的にもきわめて短時間で萎縮が生じる経過など から，一般の事故による頭部外傷とは異なった，過剩な 興奮毒性などによる損傷のメカニズムが推測されてい $3^{15) 16) 25)}$.

予防が脳損傷を防止するための最高の治療法である が, 現時点では, 二次性脳損傷を予防する方法の開発に は至っていない. 可能なかぎり受傷初期の段階から，「脳 損傷の進行を防止する」ことを念頭に置いた対応ができ るよう, 救急蘇生法の受講や効率的な救急搬送システム の構築を提唱している377)23322). 


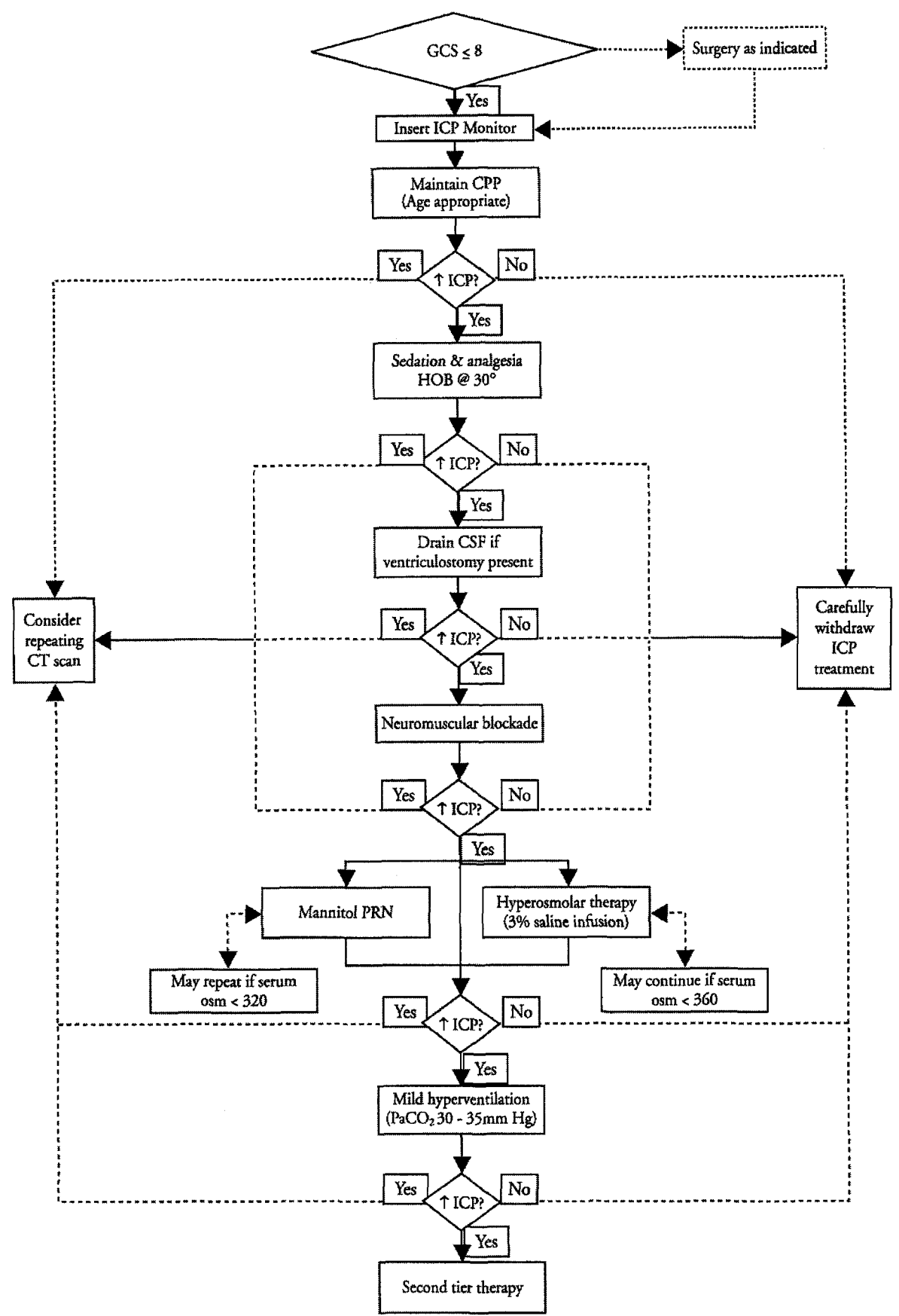

Fig. 2 The stepwise protocol for the management of severe head injury in children : First-tier therapy (Reprint with permission from Ref. 1)

GCS : Glasgow Coma Scale, ICP : intracranial pressure, CPP : cerebral perfusion pressure, HOB : head of bed, CSF : cerebrospinal fluid, CT : computed tomography, PRN : as needed

\section{Guidelines for the acute medical man- agement of severe traumatic brain injury in infants, children, adolescents ${ }^{1 / 2)}$}

アメリカの小览重症頭部外傷ガイドライン（以下，米 国ガイドライン) は, 2003 年に発表された。このガイド ラインは Brain Trauma Foundation による成人用ガイド ラインの形式を踏襲し，小児頭部外傷診療を包括的に，
病院前救護の点から外科手術適応に至るまで視点を広く 設けたものである.小児外傷センターで治療された重症 頭部外傷患者のほうが死亡率・罹患率ともに低下したと いう根拠を挙げ,「小児外傷診療に特化した救急搬送体制 の構築」などの社会的提言を行っている40).

初期治療の章では，現場にお汀る気道確保，循環安定 化の蘇生の重要性が示され，一貫した二次性脳損傷防止 が強調されている。特に小児に対する現場での気管挿管 
Table 1 Clinical topics which will be revised in the new edition of the Japanese guideline based on the level of clinical evidence

\begin{tabular}{|c|c|}
\hline & \\
\hline & 改訂のポイント \\
\hline ・レベル I & ステロイドは無効 \\
\hline ・レベル II & 低血圧（90 mmHg）の防止 \\
\hline & ICP モニターの有用性 \\
\hline & 予防的過換気は無効 \\
\hline & 栄養支援 \\
\hline & 抗痓彎剤の予防的投与 \\
\hline ・レベルIII & 低体温療法は無効 \\
\hline & 脳組織酸素分圧の測定 \\
\hline & 減圧開頭術は？？ \\
\hline
\end{tabular}

ICP : intracranial pressure

は，右主気管支への片肺挿管や食道掩管などの合併症発 生率が高いため，手技に熟練した医師のみが実施すべき である3゙)といった注意点も示される。このような視点は まさに multidisciplinary approach を実践するうえで重要 である。

頭蓋内圧（以下，ICP）六進の治療についての項目で は，ICP 測定の臨床的意義を述べ，ICP 值をターゲット とした段階的治療法が整理された（Fig. 2)。呼吸循環を 安定化させるための蘇生法を含め, 基本的かつ治療効果 がより明らかなものを First-tier, 侵襲を伴う治療であり ながら evidence としての根拠が弱いものを Secondtier として分類し， flow chart として理解できる.

米国ガイドラインにおけるレベル I 推奨項目は，(1)プ ロポフォール持続投与の禁止，(2)長期間の過換気療法は 無効であり, 有害であること, (3)受傷後 7 日以降は抗痤 攣剂による外傷性痓攣の予防効果はないこと, 以上 3 点 である. 国内外ともに小児重症頭部外傷の比較対象試験 はきわめて少なく，エビデンスレベルが下がらざるをえ なかったこと，成人を対象とした臨床研究による知見を 参考として使用されていることも今後の課題である.

\section{重症頭部外傷のガイドライン}

(改訂第 2 版, 2007 年) ${ }^{38)}$

本邦のガイドラインは，欧米と異なる医療保険制度や 医療体制の下で, 重症頭部外傷を受け入れる施設も地域 によりさまざまであることなど，日本の現状に照らし， 本邦の臨床研究やエキスパートの意見を集約した形で編 纂されている。

第 2 版では，小児頭部外傷の解説は，第 6 章「小児と
高齢者に対する治療・管理」に扔いて約 20 ページ （pp.79-99）にわたり記載されている. (1)病院到着前救護, (2)ICU での管理に区分されており, (2)の ICU 管理はさら に 13 項目に区分さ机詳述されている。参考文献として は全 44 論文が引用され，そのうち英文が 34 個と大半を 占める. 今後国内の小児頭部外傷についても臨床研究の 発表が期待されている.

ガイドラインのサイズの関係から，各項目について記 述は短く簡潔なものとなっているが，アメリカのガイド ラインの内容を「欧米文献の検証」として付記している. 誌面の都合上，詳細は『重症頭部外傷治療・管理のガ イドライン』を参照していただき，本稿では日米ガイド ラインに怙ける小児重症頭部外傷治療, 特に ICP 管理法 の相違点を比較し，さらに 2007 年以降発表された小児 重症頭部外傷の治療に関する大規模な臨床研究，すなう ち(1)重症頭部外傷に対する軽度低体温療法，(2)減圧開頭 術の有効性を踏まえ，ガイドラインの将来像について概 説する（Table 1).

\section{1 病院到着前救護}

低血圧・低酸素の是正，気道確保・酸素投与，頝椎保 護，応急処置などはガイドライン上，繰り返し重要性が 強調されている。 二次性脳損傷の進行を防止するうえで 基本的なものであり，脳神経外科医が頭部外傷の初期診 療を担当施設では, PALS (pediatric advanced life support) などの小児救急患者蘇生の学習コースを履修しておくと よ( ${ }^{5) 22)}$

現場での気道確保については，小児患者に対する気管 挿管が予後を改善させたという記載はなく，バッグバル ブマスクなどによる基本的気道確保および換気により安 定した状態が確立できれば十分である。

\section{2 専門施設への般送基準}

近年，ドクターカー,ドクターへリなどの普及により， 医師が現場において初期治療を達成できる地域も増えて いる，ガイドラインでは専門施設への搬送基準を揭げて いるが，本邦の小児救急搬送体制では，直近の救命救急 センターに収容される事例が多い.いったん救命処置を 行い，さらに高次の呼吸循環管理が可能な施設へ搬送す るシステムを有した地域もある。独立型の小児外傷セン ターが稼動している施設は存在しない.

\section{3 来院時の診察上の注意点}

バイタルサインに加え，詳細に全身を評価することが 重要である，乳児の頭部外傷の診察では病歴の聴取をで 
きるだけ詳しく行い，虐待の疑いについて留意する。平 成 22 年 (2010 年) 度の児童相談所相談件数は約 43,000 件であり，重症例も増加しつつある．救急室において疑 わしい症例は入院させ，総合的判断を待つことが望まし w.

\section{4 来院後の初期治療}

「全身状態の瞬時把握と救急処置が全てに優先する」と されており，ガイドライン内には小児の年齢に応じたバ イタルサインの正常値も揭示されている。また静脈路確 保が困難な場合には骨髄針を用いて骨髄内輸液を行うこ とや, 低血圧時に細胞外液 $20 \mathrm{ml} / \mathrm{kg}$ の急速輸液を行うこ とも言及している. 小児頭部外傷患者における低血圧, 低酸素の合併防止についての意識啓発は，ガイドライン の意義であるといえる。

\section{ICU での管理}

\section{ICP の測定の適応と方法}

本邦のガイドラインに対するコンプライアンス率調査 によれば，ガイドライン推奨の ICP モニタリング実施率 は $30 \%$ 以下との報告がある ${ }^{37)}$ 。また小児例に対し，ICP センサー挿人を実施しない施設も多い. ICP センサーの 使用自体が外傷の転帰を改善したという根拠はないもの の, ICP 光進は予後不良と強い相関を示すため, ICP 管 理は予後改善の必要条件であるといえる。本邦では脳室 ドレナージによる ICP 測定よりも脳実質センサーの使 用例が多い. 小児では ICP 克進の臨床症状が明らかにな らない場合や，意識レベル評価が困難であるため，ICP を数值として客観的に追跡することにより，管理が容易 となる点もある。

\section{ICP の治療閾值}

米国ガイドラインでは, ICP $20 \mathrm{mmHg}$ が 5 分以上持続 する場合を ICP 充進と定義している，年齢に応じて ICP 治療の閾値を変更する必要があるかどうかについては一 定の結論はいまだ存在しない13)。文献的には ICP 20 $\mathrm{mmHg}$ 以下を治療目標としていることが多いが, サイ ズ・重量・水分含有量などを考慮した場合, 乳幼児でも ICP $20 \mathrm{mmHg}$ が閾値として適正である根拠はない.この ため, 現時点では絶対值として ICP 值を単独のターゲッ トとした治療法ではなく, 脳環流圧 (CPP) や頚静脈洞 内酸素飽和度 $\left(\mathrm{SjO}_{2}\right)$ 值, 経頭蓋ドップラーエコーなど の画像所見を総合した管理が好ましいと考学られてい $3^{27734)}$.

\section{3. 脳灌流圧 (CPP) の治療閾值}

頭部外傷後の脳血流 $(\mathrm{CBF})$ 低下や組織虚血を報告し
た論文が多い35460449)51．本来，実際の組織虚血は CBF の 直接測定により評価されるべきであるが, $\mathrm{CPP}$ と CBF が直線的に相関したことから，CPP の維持は CBF を安 定化させ, 結論として神経学的予後を改善させるという 論理である。自動調節能が作用する場合, 人為的な CPP 上昇は脳血管平滑筋収縮を誘発し CBF は一定に維持さ れるが，小児は自動調節能が未熟であり，CBF も収縮期 血圧に依存すると考えられているため, CPP 維持は成人 以上に重要である，治療閾値については年齢に応じて変 更すべきかどうか不明である。ただし CPP $40 \mathrm{mmHg}$ 以 下で死亡率と相関するといわれている ${ }^{12)}$. また小児例に おいて ICP targeted therapy と CPP targeted therapy の 有効性を比較し， CPP targeted による予後が優れていた という報告もある ${ }^{43)}$.

近年 $\mathrm{PbtO}_{2}$ などの新しいモニタリングを用いた組織低 酸素の評価法が検討されているが, CPP 自体は局所脑損 傷における組織虚血を反映しえないという報告が多 い19). 将来的には個々の患者, 損傷脳の状態に応じた治 療介入が必要となる可能性がある。

\section{4. 鎮静剤, 鎮痛剂, 筋弛緩剤の治療的使用}

致死的代謝性アシドーシスの報告を基にした小児例に 対するプロポフォールの持続的投与は禁忌であることを 知らなくてはならない音。これは米国 FDA の勧告でもあ る。十分な鎮静，筋弛緩はそれ自体が ICP 降下作用や代 謝抑制効果を期待できるという報告もある.

\section{5. 脳室ドレナージによるICP 管理}

小児例における脳室ドレナージの有効性は, 1982 年, Shapiro $ら^{45)} の$ class III studyにより報告されている。ま た Ghajar ら ${ }^{21)}$ は成人例において, 脳室ドレナージを用い て ICP を $15 \mathrm{mmHg}$ 以下に管理したことで, 死亡率が大 きく低下したと報告している，このように，米国では標 準的に行われている脳室ドレナージであるが，ガイドラ インでは GCS 8 以下の症例に対する ICP 測定および ICP 充進に対する治療の標準的手法として位置づけられ ている.

本邦に抢いても有用性を主張する報告が増えている． また髄液排出により治療を行った結果, 高浸透压利尿剂 の総使用量, 低体温管理, ICU 在室日数などが減少した という報告もある。少例では脳室サイズが狭く手技の 困難さを理由に実施しないという意見もあるが，脳室穿 刺の際の合併症についての調査では, 出血性合併症, 誤 穿刺は $1 \%$ 以下，感染などが $5 \%$ 以下とされ，その他の モニタリング法と相違ない20).

\section{6. 高張剤による治療}

本邦では小児患者に対して，マニトール，グリセオー 
ル両者が用いられるが，米国ではマニトールのみを投与 した治療内容の記載が多い.マニトール使用については, ボーラス投与を行った後 30 分以内に効果が認められな いものを無効として判断し，血漿浸透圧や腎不全のリス クに照合して，繰り返す投与回数を判断している ${ }^{44)}$. 生 体で代謝を受けない低分子物質であることから小児例に 使用することを生理的でないとみる意見もある。いずれ の場合も，正常循環血液量を維持することが推奨されて いる.

高張 $(3 \%)$ 食塩水は通常 $0.1 \sim 1.0 \mathrm{ml} / \mathrm{kg} / \mathrm{h}$ の持続投与 が標準的であるが，本邦では 3\%製剤の使用が認可され ておらず，10\%製剤を調合し代用することが多い．高張 食塩水の生理学的作用としては, (1)血液粘脹度の低下に よる脳血流改善, (2)脳血流量低下による頭蓋内血液量抒 よび頭蓋内圧降下，その他(3)神経細胞の静止膜電位の回 復，(4)心房性ナトリウムペプチドの分泌低下，(5)炎症連 鎖の停止，66拍出量改善などが挙げられている，原則 として，血液脳関門や血管自動調節能が破綻した部位の 脳組織では効果は期待できない，投与による腎不全など の合併症発生率はマニトールに比べ低いと考元られてい $ろ^{28)}$.

\section{7. 過換気療法}

「盲目的な過換気は望ましくない」と明記されている。 Bruce $ら^{9)}$ が提唱した小児重症頭部外傷急性期の脳充血. 現象は実際にはみられないということ，予防的過換気の 有効性が脳虚血を誘発する，などの臨床研究結果を受け ている。びまん性脳損傷の場合, 血管自動調節能や二酸 化炭素反応性について CT 画像では評価困難なことか ら，脳血流・脳代謝モニターを駆使しながら換気設定を

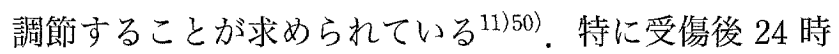
間以内はさらに脳血流量の低下が予想され，十分な注意 が必要である。横田ら ${ }^{52)}$ は, ICP 值と $\mathrm{SjO}_{2}$ 值により重症 頭部外傷病態の経時的変化を 6 区画に分類し, 各病態の 生理学的特徵を踏まえ治療することを推奨している.

\section{8. バルビツレート療法}

小児に対するバルビッレートの効果について，ICP 降 下作用は認妨秃ている一方, 予後改善との相関につい ては依然不明である。，小児に対しては脳波上の burst suppression 確認できる十分な投与量を持続的に使用 しても神経保謢效果は期待できないとされている，また ICU ぞ呼吸循環管理の可能な環境下で実施すること が必須である、バルビッレートによる心筋抑制, 低血圧 の合併に留意する。難治性の頭蓋内圧元進では, 脳組織 がきわ女て脆弱な状態にあり,わずかな低血圧であって も二次性脳損傷が増悪する可能性が高い。このため十分
な補液と昇圧剂の併用，また循環動態の鋭敏なモニタリ ングができない場合には盲目的な使用を避けるべきであ $ろ^{41)}$.

\section{9. 低体温療法}

小児重症頭部外傷に対する低体温治療の有効性を論じ た RCT（randomized controlled trial）では，主に低体温 の治療応用の安全性と神経学的予後が評洒検討されてき た. 2008 年，トロント小児病院を中心として行われた RCT は，その有効性について否定的な結論を報告した。 “受傷後 8 時間以内に低体温状態に到達し, 頭蓋内圧古 進の有無にかかわらず 24 時間に限り 33〜 34 $4^{\circ} \mathrm{C}$ 低体温 管理を行った小児重症頭部外傷症例”を対象とした結果 であり，依然アジア諸国（日本，韓国，中国など）から は “低体温の頭蓋内压降下作用”を強く主張した報告も

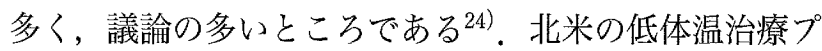
ロトコールは概して管理時間が短く設定されたものが多 く, 平均 $24 \sim 48$ 時間の低体温維持で治療を終了する. また比較的急速に復温を行っている ${ }^{14)}$ 。一方, 低体温の 強力な ICP 降下作用を治療に用いる本邦や中国などの プロトコールは，より長い低体温維持期間を要する。ま た復温速度も緩徐なものが多い，従来，急速な速度での 復温や 48 時閒以内に開始された復温は, 高率にリバウ ンド現象（ICP 上昇）を惹起することが知られており， 不適正な速度での復温によって血液循環動態が不安定化 し，二次的神経損傷が付加された可能性の有無を論じる ことは妥当であると考える。低体温において，(1)ICP monitoring の必要性, (2)冷却期間, (3)復温の開始判断と 復温速度については今後さらに検討される必要がある。

\section{0. 減圧開頭法}

小児例に対する有効性について, Polin ら ${ }^{42)}$ は $80 \%$ の 症例に良好な転帰を認めたと報告し, Taylor ら ${ }^{477}$ は唯一 の RCT を行い，減圧群の $54 \%$ が予後良好を示し，非減 圧群の $14 \%$ に比べ良好な予後であったと報告した。ま た Jagannathan $~^{26)}$ は，“減圧開頭術は小児重症頭部外傷 例に刘して，臨床的，機能的に良好な予後をもたらしう る方法である”と結論している，過去多くの報告が，早 急な開頭こそ良好な予後をもたらすとしてきたが, 近年, 小児患者においては特に呼吸循環動態が不安定な状態で 性急に減圧開頭術を行うことで死亡率を増加させること が明らかとなっている。十分にバイタルサインが安定す る努力を継続し, ICP モニタリングを行い, 経時的な CT 撮影や神経学的所見の評価が必須である.

\section{1. ステロイド剤の使用}

ステロイドの使用については, 内因性コルチゾール分 泌抑制や血糖上昇などの合併の可能性が報告されて扮 
り，その有効性も否定されている．現在では重症頭部外 傷の治療上使用される理由はない18).

\section{2. 抗てんかん剂}

小児，特に乳幼児では受傷後 7 日以内に発生する早期 てんかんの危険性が高いとされ，重症例に対し受傷早期 からの抗てんかん剂の予防的投与が推奨されている。 ま た 2 歳以下の乳児における早期てんかん発生の危険因 子について，(1)低血圧の合併，(2)被虐待児，(3)GCS 8 以 下のいずれにおいても投与が好ましい.

晚期てんかんの発生に対する予防的投与の効果はな く, 現在は推奨されていないため, 早期てんかんの予防 目的で投与されていた抗てんかん剂はいずれかの時点で 中止をすることになる．中止のための具体的指針は存在 しないが，各種画像，脳波，血中濃度の検査を行い，同 時に臨床的な経過を考慮して半減するなどの方法が一般 的である30)31)48).

\section{最後に}

“わが国は先進国である”とすべての国民が信じて疑わ ないであろう。しかし 1４歳の小児における不慮の事 故による死亡率は, 他の先進諸国と比して 10 倍以上の 高さを依然維持しているのである，小児外傷の死因の第 1 位が頭部外傷である以上，日本の脳神経外科医は真剣 にこの現状を認識しなくてはならない. 小児外傷死亡率 の高さの原因を病院前救護の質や救急初期治療に責任転 嫁する前に, “小児頭部外傷”そのものが正しく認識され ているか，もう一度真摰に振り返り，襟を正さねばなる まい.

1970 年, 中村ら ${ }^{36)}$ の名著『小坚頭部外傷の剖検所見と 臨床』の序文において, 故佐野圭司先生は, “脳神経外科 医にとって幼小児頭部外傷の特殊性を知っておくことは （中略）必要不可欠の資格であり，責務である”と述べら れている。この一文を付し，未来の脳神経外科を担うわ れわれが，さらなる外傷臨床の発展に尽くすことを誓わ ねばならない。

\section{文 献}

1) Adelson PD, Bratton SL, Carney NA, Chesnut RM, du Coudray HE, Goldstein B, Kochanek PM, Miller HC, Partington MP, Selden NR, Warden CR, Wright DW: Guidelines for the acute medical management of severe traumatic brain injury in infants, children, and adolescents. Chapter 17. Critical pathway for the treatment of established intracranial hypertension in pediatric traumatic brain injury. Pediatr Crit Care Med 4 (3 Suppl) : S65-67, 2003.
2) Adelson PD, Bratton SL, Carney NA, Chesnut RM, du Coudray HE, Goldstein B, Kochanek PM, Miller HC, Partington MP, Selden NR, Warden CR, Wright DW: Guidelines for the acute medical management of severe traumatic brain injury in infants, children, and adolescents. Chapter 19. The role of anti-seizure prophylaxis following severe pediatric traumatic brain injury. Pediatr Crit Care Med 4 (3 Suppl): S72-75, 2003.

3) Adelson PD, Ragheb J, Kanev P, Brockmeyer D, Beers SR, Brown SD, Cassidy LD, Chang Y, Levin H: Phase II clinical trial of moderate hypothermia after severe traumatic brain injury in children. Neurosurgery $\mathbf{5 6}: 740^{-}$ 754, 2005.

4) Alexander M: Mild traumatic brain injury: Pathophysiology, natural history, and clinical management. Neurology 45: 1253-1260, 1995.

5）荒木 尚，山本 守，三重野英樹，中村英一郎，田久保 啓誌，北薗雅敏，横堀将司，渥美生弘，布施 明，佐藤 秀貴, 横田裕行, 山本保博: 救急医と脳神経外科医の連 携: 小児神経外傷における PALS と Trauma Team Leadership. Neurosurg Emerg 14:18-25, 2009.

6) Beaumont A, Marmarou A, Ward J: Intracranial hypertension mechanism and management. in McLone DG (ed) : Pediatric Neurosurgery: Surgery of the Developing Nervous System. Philadelphia, WB Saunders, 2001, pp.619-633.

7) Brain Trauma Foundation: Guidelines for the management of severe traumatic brain injury. J Neurotrauma 24 (Suppl 1) : S1-S106, 2007.

8) Bray RJ : Propofol infusion syndrome in children. Paediatric Anaesth $\quad 8:$ :91-499, 1998.

9) Bruce D, Raphaely R, Goldberg Al, Zimmerman RA, Bilaniuk LT, Schut L, Kuhl DE: Pathophysiology, treatment and outcome following severe head injury in children. Childs Brain 5: 174-191, 1979.

10) Caffey $\mathrm{J}:$ On the theory and practice of shaking infants: Its potential residual effects of permanent brain damage and mental retardation. Am J Dis Child 124:161-169, 1972.

11) Chaiwat $O$, Sharma $D$, Udomphorn $Y$, Armstead WM, Vavilala MS : Cerebral hemodynamic predictors of poor $6^{-}$ month Glasgow Outcome Score in severe pediatric traumatic brain injury. J Neurotrauma 26: 657-663, 2009.

12) Chambers IR, Kirkham FJ: What is the optimal perfusion pressure in children suffering from traumatic coma? Neurosurg Focus 15: E3, 2003.

13) Chambers IR, Jones PA, Lo TY, Forsyth RJ, Fulton B, Andrews PJ, Mendelow AD, Minns RA: Critical thresholds of intracranial pressure and cerebral perfusion pressure related to age in paediatric head injury. J Neurol Neurosurg Psychiatry $77: 234-240,2006$.

14) Clifton GL, Miller ER, Choi SC, Levin HS, McCauley S, Smith KP Jr, Muizelaar JP, Wagner FC Jr, Marion DW, Luerssen TG, Chesnut RM, Schwartz M: Lack of effect of induction of hypothermia after acute brain injury. $N$ Engl J Med 344: 556-563. 2001.

15) Duhaime AC, Gennarelli TA, Thibault LE, Bruce DA, Margulies SS, Wiser R: The shaken baby syndrome: A clinical, pathological, and biomechanical study. $J$ Neurosurg 66: 409-415, 1987.

16) Duhaime AC, Durham $S$ : Traumatic brain injury in infants: the phenomenon of subdural hemorrhage with hemispheric hypodensity ("Big Black Brain"). Prog Brain 
Res 161: 293-302, 2007.

17) Faden AI, Demediuk P, Panter SS, Vink R: The role of excitatory amino acids and NMDA receptors in traumatic brain injury. Science 244: 789-800, 1989.

18) Fanconi S, Klöti J, Meuli M, Zaugg H, Zachmann $M$ : Dexamethasone therapy and endogenious cortisol production in severe pediatric head injury. Intensive Care Med 14: 163-166, 1988.

19) Figaji AA, Zwane E, Thompson C, Fieggen AG, Argent $\mathrm{AC}$, Le Roux $\mathrm{PD}$, Peter JC: Brain tissue oxygen tension monitoring in pediatric severe traumatic brain injury Part 1: Relationship with outcome. Childs Nerv Syst 25: 1325-1333, 2009.

20) Gambardella G, Zaccone C, Cardia C, Tomasello F : Intracranial pressure monitoring in children: Comparison of external ventricular device with the fiberoptic system. Child Nerv Syst 9:470-473, 1993.

21) Ghajar JBG, Hariri RJ, Patterson RH : Improved outcome from traumatic coma using only ventricular cerebrospinal drainage for intracranial pressure control. Adv Neurosurg 21: 173-177, 1993.

22) Gunst M, Sperry JL, Ghaemmaghami V, Gunst RF, Friese RS, Frankel HL, Gentilello LM, Shafl S: Increased risk of death associated with hypotension is not altered by the presence of brain injury in pediatric trauma patients. $A m J$ Surg 194:741-745, 2007.

23) Hutchison J, Ward R, Lacroix J, Hébert P, Skippen P, Barnes M, Meyer P, Morris K, Kirpalani H, Singh R, Dirks P, Bohn D, Moher D : Hypothermia pediatric head injury trial: the value of a pretrial clinical evaluation phase. Dev Neurosci 28: 291-301, 2006.

24) Hutchison JS, Ward RE, Lacroix J, Hébert PC, Barnes MA, Bohn DJ, Dirks PB, Doucette S, Fergusson D, Gottesman R, Joffe AR, Kirpalani HM, Meyer MG, Morris KP, Moher D, Singh RN, Skippen PW : Hypothermia therapy after traumatic brain injury in children. $N$ Engl $J$ Med 358: 2447-2456, 2008.

25) Ichord RN, Naim M, Pollock AN, Nance ML, Margulies SS, Christian CW: Hypoxic-ischemic injury complicates inflicted and accidental traumatic brain injury in young children : the role of diffusion-weighted imaging. $J$ Neurotrauma 24: 106-118, 2007.

26) Jagannathan J, Okonkwo DO, Dumont AS, Ahmed H, Bahari A, Prevedello DM, Jane JA Sr, Jane JA Jr: Outcome following decompressive cra niectomy in children with severe traumatic brain injury: A 10-year single-center experience with long-term follow up. $J$ Neurosurg 106 (4 Suppl Pediatrics) : 268-275, 2007.

27) Jagannathan J, Okonkwo DO, Yeoh HK, Dumont AS, Saulle D, Haizlip J, Barth JT, Jane JA Sr, Jane JA Jr : Longterm outcomes and prognostic factors in pediatric patients with severe traumatic brain injury and elevated intracranial pressure. J Neurosurg Pediatr 2: 240-249, 2008.

28) Khanna S, Davis D, Peterson B, Fisher B, Tung H, O'Quigley J, Deutsch R: Use of hypertonic saline in the treatment of severe refractory posttraumatic intracranial hypertension in pediatric traumatic brain injury. Crit Care Med 28: 1144-1151, 2000.

29) Kraus JF, McArthur DL, Silverman TA, Jayaraman M: Epidemiology of brain injury. in Narayan RK, Wilberger JE Jr, Povlishock JT (eds) : Neurotrauma. New York, McGrawHill, 1996, pp.13-29.
30) Lewis RJ, Yee L, Inkelis SH, Gilmore D : Clinical predictors of post-traumatic seizures in children with head trauma. Ann Emerg Med 22 : 1114-1118, 1993.

31) Liesemer K, Bratton SL, Zebrack CM, Brockmeyer D, Statler KD: Early post-traumatic seizures in moderate to severe pediatric traumatic brain injury: Rates, risk factors, and clinical features. $J$ Neurotrauma 28:755-762, 2011.

32) Marion DW, Penrod LE, Kelsey SF, Obrist WD, Kochanek PM, Palmer AM, Wisniewski SR, DeKosky ST: Treatment of traumatic brain injury with moderate hypothermia. N Engl J Med 336: 540-546, 1997.

33) Martinon $\mathrm{C}$, Duracher $\mathrm{C}$, Blanot $\mathrm{S}$, Escolano S, De Agostini M, Périé-Vintras AC, Orliaguet G, Carli PA, Meyer $P G$ : Emergency tracheal intubation of severely head-injured children: Changing daily practice after implementation of national guidelines. Pediatr Crit Care Med 12:65-70, 2011.

34) Morris KP, Forsyth RJ, Parslow RC, Hawley CA: Intracranial pressure complicating severe traumatic brain injury in children : Monitoring and management. Intensive Care Med 32: 1606-1612, 2006.

35) Muizelaar JP, Marmarou AM, DeSalles AA, Ward JD, Zimmerman RS, Li Z, Choi SC, Young HF : Cerebral blood flow and metabolism in severely head-injured children. Part 1: Relationship with GCS score, outcome, ICP, and PVI. J Neurosurg 71: 63-71, 1989.

36）中村紀夫，平川公義，橋爪敬三：小児頭部外傷の剖検所 見と臨床。脳と発達 2:23-30，1970.

37) Narayan RK, Kishore PR, Becker D, Ward JD, Enas GG, Greenberg RR, Domingues Da Silva A, Lipper MH, Choi SC, Mayhall CG, Lutz HA 3rd, Young HF: Intracranial pressure: to monitor or not to monitor? I Neurosurg 56: 650-659, 1982.

38）日本神経外傷学会：重症頭部外傷治療・管理のガイドラ イン 第 2 版。東京，医学書院，2007.

39) Palmer AM, Marion DW, Botscheller ML, Swedlow PD, Styren SD, DeKosky ST: Traumatic brain injury-induced excitotoxicity assessed in a controlled cortical impact model. J Neurchem 61:2015-2024, 1993.

40) Pfenninger J, Kaiser G, Lütschg J, Sutter M: Treatment and outcome of the severely head injured child. Intensive Care Med 9: 13-16, 1983.

41) Pittman T, Bucholz R, Williams D: Efficacy of barbiturates in the treatment of resistant intracranial hypertension in severely head injured children. Pediatr Neurosci 15: 13-17, 1989 .

42) Polin RS, Shaffrey ME, Bogaev CA, Tisdale N, Germanson $\mathrm{T}$, Bocchicchio B, Jane JA: Decompressive bifrontal craniectomy in the treatment of severe refractory posttraumatic cerebral edema. Neurosurgery $41: 84-92,1997$.

43) Prabhakaran P, Reddy AT, Oakes J, King WD, Winkler MK, Givens TG: A pilot trial comparing cerebral perfusion pressure-targeted therapy to intracranial pressuretargeted therapy in chidren with severe traumatic brain injury. $J$ Neurosurg 100 (5 Suppl Pediatrics) : 454-459, 2004.

44) Schwartz ML, Tator CH, Rowed DW, Reid SR, Meguro K, Andrews DF: The University of Toronto Head Injury Treatment Study: A prospective, randomized comparison of pentobarbital and mannitol. Can J Neurol Sci 11:434440, 1984 
45) Shapiro K, Marmarou A: Clinical application of the pressure-volume index in treatment of pediatric head injuries. J Neurosurg 56:819-825, 1982.

46) Stein SC, Spittell C: The Head Injury Severity Scale (HISS) : A practical classification of closed- head injury. Brain Inj 9: 437-444, 1995.

47) Taylor A, Butt W, Rosenfield J, Shann F, Ditchfield M, Lewis E, Klug G, Wallace D, Henning R, Tibballs J : A randomized trial of very early decompressive craniectomy in children with traumatic brain injury and sustained intracranial hypertension. Childs Nerv Syst 17: 154-162, 2001.

48) Tilford JM, Simpson PM, Yeh TS, Lensing S, Aitken ME, Green JW, Harr J, Fiser DH : Variation in therapy and outcome for pediatric head trauma patients. Crit Care Med 29: 1056-1061, 2001.

49) Tontisirin N, Armstead W, Waitayawinyu P, Moore A,
Udomphorn Y, Zimmerman JJ, Chesnut R, Vavilala MS : Change in cerebral autoregulation as a function of time in children after severe traumatic brain injury: A case series. Child Nerve Syst 23: 1163-1169, 2007.

50) Van Harreveld A, Fifkova E: Light- and electron-microscopic changes in central nervous tissue after electrophoretic injection of glutamate. Exp Mol Pathol 15:61-81, 1971.

51) Vavilala MS, Tontisirin N, Udomphorn Y, Armstead W, Zimmerman JJ, Chesnut R, Lam AM: Hemispheric differences in cerebral autoregulation in children with moderate and severe traumatic brain injury. Neurocrit Care 9:45$54,2008$.

52）横田裕行：ICU 管理。重森 稔, 片山容一，小林士郎, 徳富孝志 (編) : 小児頭部外傷. 東京, 医学書院, 1996, pp.176-192.

要

旨

小児重症頭部外傷ガイドライン

荒木 尚 師田 信人

小児重症頭部外傷に対する診療は，発達段階にある中枢神経組織の解剖学的，生理学的特徵を踏ま えて行うことが大切である. 特に病院搬入前の呼吸・循環の状態が患児の予後に強く影響するため, 受傷現場からの救急初期治療の意義は大きい.このため標準的手法を掲載したガイドラインは，治療 の質の向上や医療者の教育における有用性に期待をもたれている，成人頭部外傷に比較して比較的頻 度が少なく，臨床研究結果のエビデンスレベルが十分ではない場合もあるが，外傷の精神神経学的影 響など, 高次脳機能や画像診断法をはじめとした課題について今後も検討される必要があろう. 